\title{
Evaluation of School Culture In Character Building at Ummul Quro Elementary School in Bogor, Indonesia
}

\author{
Ariah $^{1}$ Fasli Jalal $^{2}$ and Asep Supena ${ }^{3}$ \\ Postgraduate Student ${ }^{1}$ and Professor ${ }^{2-3}$ \\ Basic Education \\ State University of Jakarta \\ East Jakarta \\ Indonesia
}

\begin{abstract}
Schools have an important role in shaping the personality of students through character education. The importance of building character in the school become the principal source of a nation because the nation great is the nation that has a strong character and has high competence. One of building character in school is through the school culture.

This study aimed to analyze and evaluate the implementation of the school culture in character building at Ummul Quro school in Bogor, Indonesia. This research method is qualitative evaluative model Stake's Countenance. Data collection techniques used were observation, interviews, and documentation. Then the data were analyzed using analysis techniques model of Miles and Huberman, which consists of data collection (later in the reduction), data presentation, and verification (conclusion).

These results indicate that the building of character through the implementation of a school culture should focus on habituation to represent the values of the main character is a priority of the school. Habituation is integrated into all activities in the school as reflected in the atmosphere and environment conducive school.
\end{abstract}

Key Words: Character, Culture School, Evaluation.

\section{INTRODUCTION}

Schools have an important role in creating human resources for competence in accordance with the times. In addition, the school also acts provide basic concepts in shaping the personality of students through character education. Thomas Lickona stated that the character is a reliable inner disposition and be used to respond to various situations in a way that morality. ${ }^{1}$ Moral showed a good attitude.

Being the best generation is the hope of all nations. However,based on a number of phenomena now the issue is still found in the character of the future generation. Problems character in these students was heavily influenced by many factors, one of which is education in schools. The school is a means of formation and character development of students who require special attention, such as the presence of professional teachers, curriculum taught, a conducive environment, the learning process that contains character values, and school culture.

The importance of building character in the school become the principal source of a nation. because the nation Great is the nation that has a strong character and have high competence, which is growing and developing of education that apply good values in all aspects of life. Schools should design and manage activities oriented building character to improve the quality of human resources.

The building of character through the application of school culture into one effort to develop character education in schools. According Montago and Dawson, culture is a way of life, that particular way of life that radiates the identity of a cluster. ${ }^{2}$ While Philips is quoted Ika Purnama Sari, argued that the culture of the school is the beliefs, attitudes, and behaviors roomates characterize a school. ${ }^{3}$ And Gail Connelly said that the school culture is comprised of reviews those elements that the make school 
safe, orderly, warm, and most importantly, conducive to teaching and learning. ${ }^{4}$ That the culture of the school is composed of elements that make the school safe, orderly, warm, and most importantly, conducive to learning and teaching.

Characteristics of school culture in every educational institution has a different value. In the implementation of school culture, cultural values were determined to be sourced and coincides with the basic cultural values application bangsa. ${ }^{5}$ Good school culture in shaping the character can suppress negative character, because the present school culture orientation-school values that precise. $^{6}$ In addition, a study conductedSukadari, Suyata, Shodiq A. Kuntoro, mentioning that the implementation of character education through the school culture significantly with behavioral development of students. ${ }^{7}$

Building Character through the school culture requires a long-term process which needs efforts of all members of the school. Therefore to obtain the achievement of the objectives the implementation of the cultural values of the school, needs to be done with the planning and implementation of maximum sustainable.

Implementation of school culture on each institution has its own peculiarities, one of which is Ummul Quro Bogor School. Ummul Quro Bogor has a character strengthening programs. With the concept and culture of the school is owned by Ummul Quro Bogor School, researchers interested in evaluating a school culture in the building of character. So the title is taken in this study is "Evaluation of School Culture In Character Building Elementary School Students" (Model Evaluation Countenance Study in School Ummul Quro Bogor, Indonesia).

\section{METHOD}

This study aims to evaluate the implementation of the cultural program of the school which applied in Ummul Quro Bogor School. The approach used in this study is a qualitative descriptive approach. In this approach, data presentation in the form of qualitative case studies both direct and indirect observation. This is based on Stake statement that, using case studies (qualitative data) can be performed to assess the activity description konteks. ${ }^{8}$

Meanwhile, according to Patton, the intended use of the data qualitative evaluation is to determine the extent to which the implementation of a program has been effectively implemented. In addition, the use of qualitative evaluation methods to add depth and detail of the assessment of data kuantitatif. ${ }^{9}$

The model used in this study is a model Stake (countenance model). In this model, there are three stages in the implementation of the program, namely antesendent (context), transaction (process), and outcomes (outputs). Each stage in the model is divided into two parts: the description (description) and assessment (judgment). Model countenance is a picture of all or overlay evaluation is not simply measuring the success of the goal. So that this model can measure all components that can be used as a decisionmaking of each focus evaluation.

Data collection techniques used in this study, are 1) observation, which aims to describe the program thoroughly and carefully. 2) Interview, to deepen the data on the activities of the cultural program of the school. Activities conducted in a structured interview using interview guide with in-depth interviews (depth interview). 3) Study of Documentation, which is a record of events that had passed, can be text, images, or the monumental works of a person.

In this study, to obtain qualitative data that is credible researchers used a technique authenticity of data (trustworthiness). Mechanical examination of the validity (trustworthiness) or test the credibility of the data is done to avoid the errors of data to be analyzed. To test the credibility to do with 1) the extension of observation, 2) an increase in perseverance, 3) triangulation, 4) a discussion with a friend, 5) analysis of negative cases, and 6) the member check.

And analysis of the data used in this research is the analysis model Miles and Huberman.Model this analysis through the three stages of the data collection phase (data collection), presentation of data (display data), and conclusion (verifying).

\section{RESULTS AND DISCUSSION}

Results and discussion of research is tailored to the stage of countenance models, namely:

\subsection{Antecendents component (Feedback)}

Based on interviews and documentation study component input in the evaluation are:

a. Base

In creating the program, there must be a foundation that made reference implementation of the cultural program of the school. Ummul Quro Bogor School in planning school cultural program refers to the national education goals set forth Law No. 20 Year 2003 on National Education System. In addition, the foundation guiding ie Statutes JSIT (Islamic School Network), Chapter III of 
Vision, Mission and Objectives, Article 8 of which become the center of the movers and empowering Islamic Schools Integrated in Indonesia towards effective schools and quality. And operationally principals make program drafting team with Principal Task Letter number: 47 / Tgs / SDIT-UQ / 01/2017.

\section{b. Stakeholder or Planner Program}

There is a sufficiency of competence of stakeholders in planning the cultural program of the school.

Stakeholders or program planners in Ummul Quro Bogor School an editorial team of Document 1 school which consists of speakers, supervisors, counselors, principals and vice-principals, as well as the coordinator level (class). The total of the drafting team is 14 people with the competence (education last) with a percentage of $58 \%$ educated Education Degree, and $42 \%$ Non Education Degree.

\section{c. Infrastructure}

Availability of facilities in supporting the sustainability of the program.

Ummul Quro Bogor School have a sufficiency within the means for the implementation of programs such as the mosque, adequate classrooms, courts, libraries, laboratories, and other facilities are in good condition.

\subsection{Component Transaction (Process)}

The implementation of the cultural program for the establishment of the school one student code implemented on the following program:

a. Greet the morning; This activity aimed to welcome the students at the school gate.

b. Morning meeting; time where conditioning students before the study began.

c. Personal Development; This activity is a mentoring group, where the goal of fostering morals.

d. Scout SIT(Islamic Scout); with emphasis on student leadership, in order to become an independent person and discipline.

e. Independent of pray; train students to be able to pray with personal awareness and honesty.

f. Ambassador clean and tidy; is one form of environmental hygiene maintenance by making the student as an ambassador charged with monitoring the cleanliness and tidiness of students each day.

g. Clean Friday; is one implementation of the entire community of Umm Quro cooperation to maintain the cleanliness of the school environment.

h. ODOP (One day one page); ODOP is habituation interact with students to keep reading the Koran.

i. Tahsin and Tahfidz Quran (T2Q); is a typical Umm Quro which aims to build a love of students to the Quran, to manifest the spirit of reading and memorizing the Quran.

j. School literacy (the best reader); school literacy is a manifestation of the implementation of the literacy movement, where it aims to foster students' interests and reading.

\subsection{Component Output}

Components of the results of the cultural program of the school are the students had expected character of the school, the eight (8) characters that become habits in Ummul Quro Bogor School, namely manners, clean and tidy, prayer with awareness, both to mortal parents, discipline, honesty, spirit recitations and memorize the Quran, and the learner. Based on the observation of character formation through the implementation of a school culture that is already well underway.

\section{CONCLUSION}

Based on the findings of the evaluation has been done, concluded that:

a. On the input component, in making a program in Ummul Quro Bogor School own foundation which is used in forming the character of students through the implementation of the school culture. Having a competent program planners and have infrastructures that support the implementation of the program.

b. In the process components, Ummul Quro Bogor School create habituation program undertaken as a form of achieving the vision of the school's mission to make the program 1) greet the morning; 2) Morning meeting; 3) Personal Development; 4) Scout SIT; 5) Independent in pray; 6) Friday net; 7) ODOP (One day one page); 8) ODOP (One Day One page) 9) Tahsin and Tahfidz Quran (T2Q), 10) School literacy (the best reader). It is nothing but a form of habituation to buiding character in students.

c. In the result component, character of the school culture in Ummul Quro School Bogor are polite, clean and tidy, prayer with awareness, good to parents, discipline, honesty, spirit of reading and memorizing the Koran, and the learner. 


\section{REFERENCES}

[1] Thomas Lickona, Character Education Complete Guide Educating Students become Smart and Good. Translations Lita S. (Bandung: Nusa Media, 2013) p. 72

[2] Daryanto, Culture and Climate Management School (Yogyakarta: Gava Media, 2015), p. 1

[3] Purnama Ika sari, Perception Teachers On School Culture At high schools in the District Fifty Cities. Journal of Educational Administration Vol. 2.No. 1, June 2014

[4] Gail Connelly.School Culture: An Accurate View. Postscript

[5] Deni Damayanti Implementation Guide Character Education in Schools (Yogyakarta: Araska, 2014), p. 56

[6] Vladimira Hornackova, et al. Analysis and Evaluation of School Culture in Kindergarten. Procedia Social Sciences and Humanities, ICEEPSY, 2013.

[7]Sukadari, Suyata, Shodiq A. Kuntoro, Ethnographic Research On School Culture In Character Education Primary Schools. Journal of Educational Development: Foundations and Applications. Volume 3, No. 1, June 2015 (58-68)

[8] Wirawan.Evaluasi: Theory, Model, Standard, Evaluation, and Profession (Jakarta: Rajawali Press, 2012), p. 52

[9] Michael Quinn Patton, Qualitative Evaluation Method. Translated by Budi Puspo Priyadi (Yogyakarta: Student Library, 2009), p. 37 